\title{
7 \\ Did community consultation cruel climate change?
}

\author{
Ron Ben-David
}

By way of introduction, 2006 was not a particularly exceptional year in history. No empires collapsed. There were no memorable assassinations. We were spared political scandal of any note. It was the year, however, that Twitter was launched and Pluto was demoted to a dwarf planet. It was also the year that Cyclone Larry devastated a large swathe of the Queensland coast only months after Hurricane Katrina wreaked havoc in New Orleans and the Gulf of Mexico. In my part of the world, Melbourne, 2006 was the year it stopped raining. In Melbourne, the level of our water storages became a topic for daily discussion on the nightly news and in the print media; the Age ran a countdown clock-the number of days until Melbourne ran out of water, the number of days until Doomsday.

In October 2006, an unassuming official in Her Majesty's Treasury published a lengthy report into the economic effects of climate change (Stern 2007). Until that time, climate change—or 'global warming', as it was then known — was viewed as a fringe issue for greenies only. Nicholas Stern's report changed all that. Seemingly overnight, climate change moved from the greenstream into the mainstream. In Australia, the unfolding drought supercharged the shift in public attitudes towards climate change. It was some time either very late in 2006 or early in 2007 that I started hearing chatter of the possibility of state governments commissioning an Australian Stern Report. The chatter quickly dissipated. 
Then, out of the blue, on 30 April, the then leader of the federal opposition Kevin Rudd and the premier of Queensland Anna Bligh announced on behalf of the states and territories that Professor Ross Garnaut had been commissioned to conduct a review into the economic and policy implications of climate change for Australia (Garnaut 2008a). Consider that for a moment: this review by the states and territories was announced by the leader of the federal opposition. I am unaware if this arrangement has any precedent in the history of the Australian Federation but it was certainly very unusual.

Within hours of the announcement, I found myself appointed to head the review's secretariat. It was to be one of the great privileges of my public service career to work with Ross and our incredibly dedicated team. It was an 18-month adventure that consumed us completely and in which we delighted. In my early discussions with Ross, a few principles quickly emerged about how we would conduct the review. It would be a very open process of enquiry intended to engage the community as broadly as possible. We would take nothing for granted and nothing as given. Instead, we would scrutinise and test every fact, assumption, assertion and idea that was presented to us, and we agreed to an approach where there would be no surprises: any conclusions that we were to reach would first be disclosed fully and tested publicly.

I have no idea how many discussions, meetings and public forums we held around the country, but it must have run into the hundreds. Likewise, I can't remember how many papers we released or how many speeches Ross delivered during the review. But we used every occasion possible to air publicly our findings and thoughts.

On 21 February 2008, Ross delivered an interim report to premiers and chief ministers and the new Rudd Labor Government in Canberra. A subsequent meeting of the premiers and chief ministers in Adelaide provided the perfect opportunity for him to hand over the report formally. Our communications manager insisted Ross hold a press conference after the official event. Sitting in the airport lounge en route back to Adelaide, I watched it on Sky News. I was awestruck. Something extraordinary was taking place in front of my eyes. The interim report was being given blanket coverage. Discussion of the report and the response of commentators continued largely uninterrupted all afternoon. This was followed by days 
of ongoing coverage and discussion in the electronic and print media. In all fairness, while the report was good, it was only very preliminary in its thinking and in its analysis.

What was going on? Why was the level of interest so intense? No doubt, it had something to do with Ross Garnaut's personal standing in the community and the media, given his long and distinguished role in modern Australian public policy. But I believe something else was going on. It was as though, finally, intelligent and open debate about climate change had been legitimised. The release of this pent-up demand for discussion, debate and analysis was to create a bow wave that was to last for the remainder of the Garnaut Review and take the public policy discussion to its high-water mark.

The month that followed that day in Adelaide could be described as La Belle Époque, a golden age of discussion, reflection and debate on all matters associated with climate change. However, I do not want to overromanticise the times. There were heated disagreements, and sometimes these were not pretty, but they were conducted in the open. And that is the unique feature of La Belle Epoque. Everything was on the table for all to see. I am very proud of the role the review played in promoting that wonderful, though ultimately fleeting, moment in the public policy discussion about climate change. But even as we were being swept along by this extraordinary tide, countercurrents were forming.

Shortly after the release of the interim report-by which I mean a few hours after the release of the report - the then Minister for Climate Change, Penny Wong, held a doorstop press conference (see Murphy 2008). She told the media that while the government welcomed the interim report as an important input, it would also be looking to other inputs. This comment came to be known, with some degree of infamy as the 'just one input' statement. Was the minister's comment intended with disrespect or malice? I strongly doubt it. What the minister said was self-evidently true. Governments do not and should never outsource policy decisions. Nevertheless, the timing of her comment and the context in which it was delivered enlivened all the vested interests who were threatened by the openness of our approach.

I will return to this matter shortly. But just to complete this little tale: some months later, Ross appeared at the National Press Club (Garnaut 2008b). When asked how he felt about being 'just one input' into the 
government's thinking, he responded, 'I'm just one input into the prime minister's thinking and he is just one input into mine'. The next few months were a whirlwind of intellectual enquiry, consultation, production and sleeplessness. Rather than share that full, long story, I will dedicate the rest of this chapter to explaining why, despite our best efforts, the community soon became so disaffected with the issues, how climate change moved from the high-water mark of public engagement reached during La Belle Époque to its near antisocial status today. I will propose four contributing factors. No doubt there are others.

First, in the Garnaut Review, we sought to make the case for action on the grounds of rational analysis using scientific and economic methods of enquiry; in modern lingo, we were committed to 'evidence-based policy'. At the same time as we were embarking on that endeavour, others sought to impress upon the community that the need for action was a moral imperative. Indeed, even the prime minister framed it as 'the greatest moral challenge of our time' (Shanahan 2007). Framing the issue in such terms certainly appeals to those who already agree- and those who already disagree will just ignore or dismiss such claims. But what does it say to the people who are not well versed in the issues, members of the community who are yet to form a view, who do not yet understand the claimed need for action?

In the words of George W. Bush, I think it says to them you are either with us or against us. Such a political message may work in the US, but I suspect it has the opposite effect in Australia. Morality is based on belief and I suspect Australians don't appreciate being told what to believe. There is another important aspect of this political involvement in the public discourse worth mentioning. Typically, when governments commission independent enquiries, in whatever form they take, the political echelon tends to withdraw from the public discussion, leaving the review to run its course and leaving the politics until later. Precisely the opposite occurred during our work. For reasons I will shortly reveal, throughout this period, the government was constantly discussing the issue in the media.

The second factor that I believe eventually eroded our efforts to engage and involve the community were the competing processes established by the newly elected government. During the preceding election campaign, the then Rudd opposition committed to establishing an emissions trading scheme within 18 months of being elected. I will not comment 
on the merits of that commitment, but what it meant was that the newly established Department of Climate Change was immediately tasked with designing and implementing the promised scheme.

That was a herculean task and I greatly admire the department's efforts. However, it meant that alongside our work, which was focused on understanding climate change and identifying the appropriate policy response, the department was running a parallel process into designing the policy response that had already been announced during the election campaign. Now, couple the department's parallel process with the minister's comment about the Garnaut Review being just one input into the policymaking process, and what happens? I suggest that it invitesno, it almost begs-all the vested interests to shop around and play off one process against another. And, to be clear, I am not just referring to the brown interests of the coal or aluminium industries.

Green interest groups, such as those advocating renewable energy and energy efficiency, were just as active in pursuing their agendas. What was perhaps the worst consequence of these coincidental reviews was that they reopened doors that had temporarily been shut to the whisperers. Our attempts to flush all the issues into the open and put them squarely in the public domain, to expose them to the sterilising effects of public scrutiny, those efforts were being thwarted as doors in Canberra were again open to those who wanted to come in and have a quiet chat. As a consequence, some of the vociferous public debate on the day of Ross Garnaut's press conference had begun to dissipate. More worryingly, some of it simply disappeared from public view altogether.

The third factor I would like to highlight was the battle over language or, more specifically, the battle over how and in what terms the public debate over climate change was to be conducted. There's nothing new about such battles. They occur every day on mostly every important issue. As the Canadian public intellectual Marshall McLuhan observed half a century ago, he or she who masters the medium, masters the message (Whitman 1981). I suppose we too tried to influence the medium in which we believed the climate change discussion needed to be conducted. We used what we believed was the language of analysis and scientific method. We did not shy away from admitting that we could not be certain about all the facts, nor did we demur from admitting that, in such instances, we could only rely on our best judgement about how to proceed — and those judgement calls were exposed for all to see and for all to question. One 
example of our attempts to establish reasonableness as the medium for discussion related to how we assessed the evidence about climate change itself. In the review, we stated:

The Review takes as its starting point, on the balance of probabilities and not as a matter of belief, the majority opinion of the Australian and international scientific communities. There are many uncertainties around the mean expectations from the science with the possibility of outcomes that are either more benign or catastrophic. (Garnaut 2008a, Chapter 2)

Admittedly, that is not the sexiest of prose. But its central message- that we do not have all the answers so the best we can do is look at the available evidence and we must do so as analytically and as rationally as we cansurely that must be the most obvious message of all. What chance did this gossamer-like message stand in moderating the medium when, at the same time, ministers were making public speeches declaring river systems will die before our eyes, we have overloaded the Earth's atmosphere, the Earth's gifts are not guaranteed, nations may disappear? And so the climate change discourse quickly degenerated to one in which people would be challenging each other with the question: do you believe in climate change? How truly inane!

Do we stand around asking each other whether we believe in quantum mechanics, even though we cannot see it with our own eyes? Do we feel compelled to profess our faith in magnetic resonance tomography before submitting ourselves to an MRI scan? We lost the battle over the medium. The medium became marked by the language of certainty and absolute commitment and, in doing so, it also became the language of exclusion and division. The language of certainty, commitment and exclusion became the medium, a medium in which there was no room or need for open engagement and genuine enquiry. For me, perhaps the tackiest example of attempting to control the medium was the name given to the proposed emissions trading scheme in 2008.

It was to be called 'The Carbon Pollution Reduction Scheme'. Pollution? No one in the scientific community refers to carbon dioxide as a pollutant, but such details didn't matter in the battle for control of the medium. By branding it a pollutant, someone was seeking to ensure they controlled what we thought about it and what we thought about anyone who might 
dare to not yet agree with us. Cynicism begets cynicism, and when such cynicism imbues the medium-well, is it any wonder the community turned its back on climate change as an issue worthy of national discussion?

The fourth reason for why we moved from the height of community engagement with the issue of climate change in early 2008 to the nadir that followed is much simpler than the other three reasons. Quite simply, the drought broke. We're all human. If, over a few years, we are filled with images of parched landscapes while, at the same time, we are bombarded from the zeitgeist about messages about climate change, then those two things become associated in our conception of the issues. When one ends, we cannot help but feel somehow the other is also lessened.

I have provided four reasons that I believe set the stage, even as early as 2008 , for the retreat of the community from the issue of climate change. First, despite our efforts to build a case for action from first principles in evidence, we could not stop others from asserting — indeed, imposingclimate change action as a matter of moral imperative rather than rational consideration. Second, despite our efforts to bring into the public spotlight all the issues and all the competing interests, we found ourselves competing with other processes that soon gave those interests avenues to retreat from the spotlight. Third, despite our efforts to establish a medium of engagement and enquiry, the language of certainty, commitment and exclusion soon became the medium. And fourth, the drought broke.

Looking at these four explanations, I admit it appears I am casting blame for the demise of climate change policy on everyone and everything but the Garnaut Review. Rest assured, I am too burdened with self-doubt to let myself get away with that. In the years since the review, as I have reflected and pondered about the role the review might have made in the unfortunate saga of climate change policy. I have repeatedly asked myself: Were we right to build the case for action from first principles and evidence? Were we right to try to bring all the issues and all the competing interests into the public spotlight? Were we right in our efforts to create a medium of engagement and enquiry for discussing the policy issues? Over and over again, I keep returning to the same three answers. Yes. Yes. And yes. We were right in trying to do all these things. I expect that most readers would agree with me. Indeed, I expect that most of us would view these three endeavours as being self-evidently right. They would seem to embody the most fundamental principles for any public enquiry, indeed, for any serious discussion of public policy. 
But here is my problem. How do we know? How do we really know that these are desirable endeavours for reviews and discussions of public policy? Maybe we don't really know. Maybe we just believe them to be true. Maybe we are confusing belief for knowledge because, for most of us, these objectives are somewhat self-serving. They fit neatly within a romantic notion of selfless public service. But has it been proven? Can it be proven that public involvement in policy formation is self-evidently desirable? And, if it be true, then is it always true? Or just sometimes true? If it only be sometimes true, then who gets to decide? And outside of us few, as well as those with a special interest, who really cares about what they decide? In the end, might public consultation really just be a sop to the vanity of the privileged few? I hope not.

Rather than conclude this chapter deep in existential angst, I will share with you one final tale from the Garnaut Climate Change Review, a tale that may help shed light on yet another consequence of extensive public consultation. As I have recounted, throughout the review we sought to make our thinking known publicly so that there would be no surprises at the end. We consulted and consulted and then we consulted some more, so much so that, by the time of the final report, we already had said pretty much everything we had to say. We succeeded so mightily in avoiding surprises that, when the review's final report was released, the news services struggled to find anything to report. Eventually, they did find something.

It lay in a table on page 542 of the report; a table on page 542 became the story. In passing, that table listed a study estimating the emissions reductions that would be gained from swapping beef for kangaroo meat. That became the news story. Page 542 even made the international news services with Bloomberg's report appearing under the headline: 'Skippy on the menu as Australia seeks to fight global warming' (Heath 2008). And you can still go to the website, it's still there, and there are the pictures that they've got accompanying the story. And that was it. After 18 months of exhaustion and exhilaration in equal measure, our efforts had come down to that headline. It was a surreal end to a very real endeavour, an endeavour that sought to engage fully the community in the development of public policy. 


\section{References}

Garnaut, R. 2008a. The Garnaut Climate Change Review-Final Report. Commonwealth of Australia, Cambridge University Press, Melbourne. Available from www.garnautreview.org.au/index.htm

Garnaut, R. 2008b. National Press Club Address-Launch of Supplementary Draft Report: Targets and Trajectories'. 5 September, Transcript. Available from www.garnautreview.org.au/CA25734E001 6A131/WebObj/Transcript-NationalPressClub-5September2008/ \$File/Transcript\%20-\%20National\%20Press\%20Club\%20-\%205 \%20September\%202008.pdf

Heath, M. 2008. 'Skippy on the Menu as Australia Seeks to Fight Global Warming'. 16 October, Bloomberg. Available from www.sott.net/ article/167594-Skippy-on-the-Menu-as-Australia-Seeks-to-FightGlobal-Warming

Murphy, K. 2008. 'Unless change is in the air, Australia could become... The Biggest Loser'. 22 February, The Age.

Shanahan, D. 2007. 'It's Monty Burns vs the Whippersnapper'. 30 April, The Australian. Available from www.theaustralian.com.au/opinion/ columnists/its-monty-burns-vs-the-whippersnapper/news-story/f82 c521b6fa5deb1131cfd8664fe38cf?sv=a08348e114e849126f2854 c6a9fe4cc1

Stern, N.H. 2007. The Economics of Climate Change: The Stern Review. Cambridge, UK: Cambridge University Press. Available from www.webcitation.org/ $5 \mathrm{nCeyEYJr?url=http://www.hm-treasury.gov.}$ uk/sternreview_index.htm

Whitman, A. 1981. 'Marshall McLuhan, Author, Dies; Declared "Medium Is the Message"'. 1 January, The New York Times. Available from archive.nytimes.com/www.nytimes.com/books/97/11/02/home/ mcluhan-obit.html 
This text is taken from Opening Government: Transparency and Engagement in the Information Age, edited by John Wanna and Sam Vincent, published 2018 by ANU Press, The Australian National University, Canberra, Australia.

doi.org/10.22459/OG.04.2018.07 